shown it to be far less effective in producing a disturbance in the venous flow. This may well explain their lack of success in preventing thrombosis in patients with malignant disease.

\section{Conclusion}

We have shown that our technique of peroperative intermittent calf compression, which produces the maximum haemodynamic disturbance in the leg veins, can reduce the incidence of postoperative thrombosis by more than $75 \%$ in patients aged over 40. More important, however, is the finding that in patients with malignant disease, hitherto regarded as "very high risk," the incidence can be reduced by almost $90 \%$. We believe our technique to be the best currently available for preventing postoperative thrombosis.

We would particularly thank Mrs. D. Berlyn for technical and secretarial help and Mrs. A. Young for technical help. We would also thank the British Heart Foundation and the Wates Foundation for their generosity in financing this investigation, the British Oxygen Company for providing the Venous Flow Stimulators, and Mr. H. E. Berry and Mr. E. Howard for allowing us access to their patients.

\section{References}

Browse, N. L., and Negus, D. (1970). British Medical fournal, 3, 615.

Clark, C., and Cotton, L. T. (1968). British fournal of Surgery, 55, 211

Flanc, D., Kakkar, V. V., and Clarke, M. B. (1968). British fournal of Surgery, 55, 742 .

Hills, N. H., Pflug, J. J., Jeyasingh, K., Boardman, L., and Calnan, J. S. (1972). British Medical fournal, $1,131$.

Miller, S. P., Sanchez-Avalos, J., Stefanski, T., and Zucherman, L. (1967). Cancer (Philadelphia), 20, 1452.

Nicholaides, A. N., Kakkar, V. V., Field, E. S., and Fish, P. (1972). In Thromboembolism, ed. V. V. Kakkar and A. J. Jouhar. Edinburgh, Churchill Livingstone.

Roberts, V. C., and Cotton, L. T. (1972). In Blood Flow Measurement, ed. V. C. Roberts. London, Sector Publishing.

Roberts, V. C., Cotton, L. T., Derry, C., and McGrath, J. A. (1973). Proceedings of the Tenth International Conference on Medical and Biological Engineering, 19-8.

Roberts, V. C., Sabri, S., Beeley, A. H., and Cotton, L. T. (1972). British fournal of Surgery, 59, 223.

Sabri, S., Roberts, V. C., and Cotton, L. T. (1971 a). British Medical , S., Roberts,

Sabri, S., Roberts, V. C., and Cotton, L. T. (1971 b). British Medical fournal, 4, 394.

Virchow, R. L. K. (1856). Thrombose and Embolie. Frankfurt.

\title{
T and B Lymphocytes: Striking Differences in Surface Membranes
}

\author{
J. N. MEHRISHI, K. ZEILLER
}

British Medical fournal, 1974, 1, 360-362

\section{Summary}

Lymphocytes can be separated by electrophoresis into cells of high and of low electrophoretic mobility. Cells of high mobility are $\mathbf{T}$ cells and those of low mobility are $\mathbf{B}$ cells, with distinct immunological functions. Biophysical and biochemical studies on physically isolated and immunologically defined $T$ and $B$ cells in CBA mice showed striking differences in the chemical composition of the surface membranes.

\section{Introduction}

Cells of lymphoid origin can be separated on the basis of the net surface charge (negative) by free-flow electrophoresis (Hannig and Zeiller, 1969) into two distinct subpopulations of high and low electrophoretic mobilities without loss of viability and with very lintle overlap (Hannig and Zeiller, 1969; Zeiller et al., 1972; Nordling et al., 1972; Seiler et al., 1974). Routine immunological methods show that the lymphocytes in the high mobility region are $T$ cells whereas the cells in the low mobility region are B cells (Zeiller et al., 1972; Nordling et al., 1972; Seiler, et al., 1974).

S.tudies (Mehrishi, 1972 a; Mehrishi, 1972 b) on normal human lymphocytes (isolated from the peripheral blood by a method such as the carbonyl iron-methyl cellulose method

Max-Planck Institut fur Biochemie, 8033 Martinsried, bei Munchen J. N. MEHRISHI, PH.D., F.R.I.C. (Present address: Department of Radiotherapeutics, University of Cambridge, Hills Road, Cambridge CB2 2QH) K. ZEILLER, M.D.
(Coulson and Chalmers, 1964) but not separated funther into subpopulations) showed the presence of positively charged groups and sulphydryl groups and at least three types of negatively charged groups in the cell periphery.

Isolation of mouse $\mathrm{T}$ and $\mathrm{B}$ lymphocytes into high mobility regions and low mobility regions raised the obvious question: is the characteristic distribution of the electrophoretic mobilities of $T$ and $B$ cells, which perform distinot immunological functions, due to some striking differences in the chemical composition of their surface membranes? The different structures in the periphery of these cells probably give them their specific surface propenties and govern the reactions taking place at the cell surface. Information on the surface chemistry of $T$ and $B$ cells would help us to understand the mechanisms of cellular interactions in molecular terms and would clearly be of much interest in immunobiological research.

We describe here the results of a study of the surface topochemistry of physically and functionally defined $T$ and $B$ cells. The study showed striking differences in the chemical composition of the peripheral regions (within $8 \AA$ from the surface) of $T$ and $B$ cells in CBA mice.

\section{Methods}

Lymph nodes, spleen, and thymus from several adult spf/ $\mathrm{CBA} / \mathrm{J}$ mice were removed, separately pooled, and the respective cell suspensions prepared for preparative free-flow electrophoresis (Hannig and Zeiller, 1969). The electrophoretic separation of the cells was carried out in a low ionic strength buffer at $6^{\circ} \mathrm{C}(210 \mathrm{~mA} 100 \mathrm{~V} / \mathrm{cm})$, using a refined model of the electrophoretic separator FF4 (Desaga, Heidelberg; Bender and Hobein, Munich) (Hannig and Zeiller, 1969). Cell fraotions from the shaded portion of the curves shown in the graph contained homogeneous 
populations of $90 \%$ viable cells of a single size. The electrophoretically isolated cells were washed in saline $(0.145$ molar $\mathrm{NaCl} / 1$. made $10^{-4}$ molar/l. with respect to $\mathrm{NaHCO}_{3}$; pH $7.2 \pm 0.2)$ and examined by cell electrophoresis $\left(25^{\circ}\right.$ $\left.\pm 0.1^{\circ} \mathrm{C}\right)$. An electrophoresis cell of a circular cross-section equipped with reversible silver-silver chloride-potassium chloride (molar) electrodes was used (Mehrishi, 1972 b); the performance of the apparatus was monitored repeatedly with saline washed erythrocytes with a mobility of $-1.08 \pm 0.04$ $\mu \mathrm{m} / \mathrm{sec} / \mathrm{V} / \mathrm{cm}$. Within 15 minutes after treatment with mild specific reagents for the reversible blocking of amino groups (2, 3 dimethylmaleic anhydride; DMA) and sulphydryl groups (6, $6^{\prime}$-dithiodinicotinic acid; DTDNA) intact viable (90\%) cells were also examined by cell electrophoresis to determine the numbers of amino groups and sulphydryl groups on a per cell basis (Mehrishi, 1972 b).

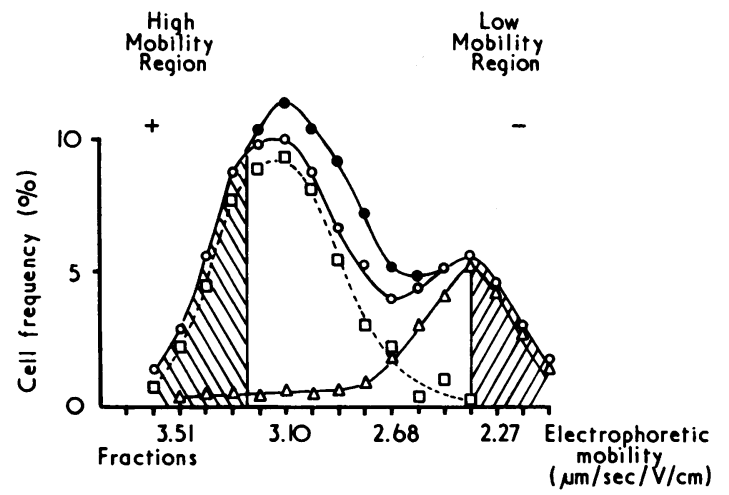

Electrophoretic distribution profiles of CBA mouse lymph node cells. $=$ Total nucleated cells. $O=$ Total lymphocytes. $\square=\theta$-positive lymphocytes. $\triangle=$ Lymphocytes positive for mouse $B$ lymphocyte specific antigen.

Vibrio cholerae neuraminidase (VCN; EC 3.2.1.18; Behringwerke, Germany) (Mehrishi, 1970) and ribonuclease (pancreatic and $T_{1}$ cells) (Mayhew and Weiss, 1968), which had been claimed by the manufacturers to have no proteolytic activity, were used for removing any susceptible groups from the surface membranes (at $37^{\circ} \mathrm{C}$ for 45 minutes). The material removed from the surface was stored for subsequent biochemical analyses. Assay for $N$-acetvlneuraminic acid (NANA) in the material removed from the cell surface by VCN treatment confirmed the presence of sialic acid in the cell periphery of both $T$ and $B$ cells (see Appendix). The enzyme treated cells were washed twice in saline and examined by cell electrophoresis.

The processing of the electrophoretic data on normal and chemically-modified cells to derive the zeta potentials (mV), surface charge densities (e.s.u. $/ \mathrm{cm}^{2}$ ), and the numbers of groups or electron charges (from the increase or decrease of mobility) per cell surface area has recently been described (Mehrishi, 1969).

\section{Results}

The numbers of groups and charges on $T$ and $B$ cells are given in the table on a per-cell basis.

The difference in the chemical constitution of the periphery of $T$ and $B$ cells was striking. B cells, with a low mobility (median value $-0.90 \mu \mathrm{m} / \mathrm{sec} / \mathrm{V} / \mathrm{cm}$ ), had phosphate groups and sulphydryl groups in the cell periphery and carried a large number of positively charged amino groups, and the $\alpha$-carboxyl groups of VCN-susceptible NANA accounted for only $17 \%$ of the total correoted electron charges. $T$ cells on the other hand exhibited a much higher mobility (median value $-1.33 \mu \mathrm{m} / \mathrm{sec} / \mathrm{V} / \mathrm{cm}$ ). In the $T$ cell peri-
Surface Membrane Groups and Charges of Mouse T and B Lymphocytes

\begin{tabular}{|c|c|c|c|c|}
\hline \multirow[t]{2}{*}{ Type of Group or Charge } & \multicolumn{2}{|c|}{$\begin{array}{l}\text { No. of Groups or Charges } \\
\text { per Cell Surface Area } \\
\left(\times 10^{5}\right)\end{array}$} & \multirow[t]{2}{*}{$\begin{array}{l}\text { No. of } \\
\text { Cells }\end{array}$} & \multirow[t]{2}{*}{$\begin{array}{c}\text { No. of } \\
\text { Experiments }\end{array}$} \\
\hline & T Cells & B Cells & & \\
\hline 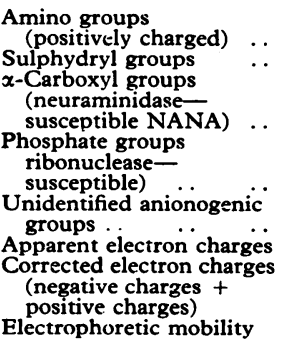 & $\begin{array}{c}6 \\
\text { Not detected } \\
24 \\
\text { Not detected } \\
76 \\
100 \\
106 \\
-1.33 \pm 0.15\end{array}$ & $\begin{array}{c}11 \\
19 \cdot 6 \\
12 \\
16 \\
43 \\
60 \\
71 \\
-0.90 \pm 0.1\end{array}$ & $\begin{array}{r}357 \\
93 \\
\\
278\end{array}$ & $\begin{array}{r}26 \\
6 \\
15\end{array}$ \\
\hline
\end{tabular}

Surface area of $T$ and B cells was estimated as $100 \mu \mathrm{m}^{2}$ (Zeiller $e t$ ial., 1974). Median values of mobilities are given because range of (s.d.) values is wide (see fig.).

phery phosphate and sulphydryl groups were not detected, the number of the positively charged amino groups was much smaller, and the number of the $\alpha$-carboxyl groups of NANA was much higher than on $B$ cells (see table). Since the contributions of the negative charges atributable to NANA or phosphate groups did not account for all the corrected electron charges (the sum of the apparent electron charges and the positively charged groups) there must have been other negatively charged groups which have not yet been identified. Such acidic groups were present on both $T$ and $B$ cells. The number of the unidentified acidic groups on $\mathbf{T}$ cells was $76 \%$ higher than on $B$ cells.

\section{Discussion}

Though we have confidence in our electrokinetic data and detailed biochemical analyses are being carried out the main purpose of this paper is to emphasize the differences which we have found in the surface topochemistry of $T$ and $B$ cells. This information is likely to be of interest to a number of research workers.

It is tempting to speculate on some of the biological implications of these differences. Though the general electrophoretic behaviour of lymphocytes from normal healthy individuals and from leukaemia patients seems to be similar (Mehrishi, 1972 b) evidence is accumulating that the cell surface of lymphocytes in chronic lymphocytic leukaemia differs from that of normal lymphocytes (Kornfeld, 1969). Also B lymphocytes in many cases of leukaemia, chronic lymphocytic leukaemia (Johansen and Klein, 1970; Wilson and Nossal, 1971; Grey et al., 1971), and Burkitt's lymphoma (Klein et al., 1968) have been reponted as having surface immunoglobulins on the cell membrane and therefore representing a B lymphocyte malignancy.

The behaviour of chronic lymphocytic leukaemia lymphocytes in vitro after treatment with phytohaemagglutinin (PHA) was explained initially on the basis of deficiency of intracellular organelles alone, and subsequently by the suggestion that PHA acted predominantly on $\mathrm{T}$ cells whereas chronic limphocytic leukaemic lymphocytes belonged chiefly to the $B$ cell line. Since the biochemical sequences leading to PHA-induced RNA, DNA, and protein synthesis and eventually to mitosis are initiated at the cell membrane, defects in the structures of the cell membrane are clearly important. The decrease in the PHA receptors of the leukaemic lymphocyte membrane may possibly be a consequence of predominant $B$ cell involvement in leukaemia but it may also refleot the changes in membrane structures associated with neoplastic and potentially malignant cells.

We believe that the present study of the surface membranes of $T$ and $B$ cells will lead to a better understanding 
of the molecular mechanism of the interactions in which these cells participate. A combination of the methods described for obtaining data on $T$ and $B$ cells may be developed for clinical use, especially for leukaemias.

Phillips and Roitt (1973) reported that B cells in man can be transformed by PHA, strongly suggesting that PHA transformation is thus an unreliable criterion of $\mathrm{T}$ cell numbers in the human species. Also, quite recently, Dickler et al. (1974) reported that when the $B$ and $T$ cell markers were evaluated simultaneously on individual (human) lymphocytes a small, real subpopulation reproducibly bore both markers.

Clearly care must be taken in using the present immunological methods to attribute the cell surface markens of either $\mathrm{T}$ or $\mathrm{B}$ cells as absolute. The extrapolation between species in relation to the distinguishing characteristics of the two cell types is also hazardous.

Our approach should be useful in establishing a quantitative chemical basis at the cellular level and characterizing cell types by physico-chemical methods (Mehrishi, 1972 b). There is a pressing need for such studies on cell types in disease.

We thank Professors G. Ruhenstroth-Bauer and K. Hannig for their interest in this work, Professor G. Uhlenbruck for some of the NANA assays, and Dr. N. Taptiklis for stimulating discussions. The use of the cell electrophoresis apparatus constructed at Cambridge was made possible through the kind permission of Professor J. S. Mitchell, head of the Cambridge University Department of Radiotherapeutics, and the Cancer Research Campaign. We thank Miss K. Axt, Mrs. Carola Eckelt, and Mrs. Rita Wiemeyer for technical help. The work was also supported by grants from the Deutsche Forschungsgemeinschaft.

\section{Appendix}

Marked intramembraneous differences between $\mathbf{T}$ and $\mathbf{B}$ cells, not directly seen in ultra-thin sections, have also been shown by electron microscopy of replicas of membranes of mouse lymphocytes prepared by freeze-fracturing (Mandel, 1972).

The initial and critical event in lymphocyte stimulation by both specific (antigen) and non-specific agents-for example, phytomitogens-is the combination of the agents with binding sites on or in the lymphocyte. Evidence is now available that VCNsusceptible NANA molecules of the lymphocyte surface are the binding sites for PHA (Lindahl-Kiesling and Peterson, 1969; Kornfeld, 1969; Johanson and Klein, 1970; Zatz et al., 1972) and that VCN treatment completely blocks the PHA-absorptive capacity of lymphoid cells and the mitogenic effects of PHA (Adler et al., 1972). The proposal that "the $\alpha$-carboxyl groups of VCN-susceptible sialic acid residues in the cell periphery are the sites for the binding of PHA" now seems plausible in view of recent finding that sialic acid is present in the periphery of both $T$ and $B$ cells, though in much smaller amounts in B cells (table I), and that B cells under certain conditions do respond to PHA (Phillips and Roitt, 1973). The response of B cells to PHA, especially in three-day cultures, was not observed before, perhaps because the number of carboxyl groups of sialic acid is too few for the PHA binding to be effective (Mehrishi 1972 b).
In the above preliminary paper the results of biochemical analyses of the material removed from the cell surface, which is still being investigated thoroughly, were not included. As stated earlier, the presence of NANA in the cell periphery was confirmed from the analyses. During the past 10 years, however, various workers have found no close relation between the loss of the $\alpha$ carboxyl groups of cell-surface NANA by VCN treatment and a decrease in the electron charges per cell surface area as estimated from electrophoretic data. The seeming futility of trying to correlate the loss of NANA molecules released by enzyme treatment with a decrease in the electron charges per cell surface area calculated from the electrophoretic mobility of treated cells has often been emphasized (Mehrishi, 1972 b). Invariably more NANA is released than would be expected from the electrophoretic data-assuming that the loss of one molecule of NANA corresponds to the loss of one electron charge (1:1 ratio). This assumption may seem reasonable but its validity remains to be established.

The evidence for the sulphydryl groups is, however, most satisfac:ory. Analyses of the supernatant after treatment of B cells with DTDNA (ultraviolet absorption peak $290 \mathrm{~nm}$ ) for 20 minutes (at $18^{\circ} \mathrm{C}$ ) to estimate the amount of the 6-mercapto-nicotinic acid (6MNA) (ultraviolet absorption peak $344 \mathrm{~nm}$ ) indicated the presence of sulphydryl groups blocked in the cell periphery (Mehrishi, 1972 b). There was good agreement between the number of sulphydryl groups per cell surface area calculated from the electrophoretic data on DTDNA-treated cells and the ultraviolet spectrophotometric data on the released 6MNA. It was not the prime purpose of the above paper to discuss the biochemical data in detail.

\section{References}

Adler, W. H., Osunkoya, B. O., Takiguchi, T., and Smith, R. T. (1972). Cellular Immunology, 3, 590.

Coulson, A. S., and Chalmers, D. G. (1964). Lancet, 1, 468.

Dickler, H. B., Adkinson, N. F., jun., and Terry, W. D. (1974). Nature, $247,213$.

Grey, H. M., Rabellino, G., and Pirofsky, B. (1971). fournal of Clinical Investigation, 50, 2368 .

Hannig, K., and Zeiller, K. (1969). Hoppe-Seylers Zeitschrift für physiologische Chemie, 350, 467.

Johanson, B., and Klein, E. (1970). Clinical and Experimental Immunology, 6,421 .

Klein, E., et al. (1968). Cancer Research, 28, 1300.

Kornfeld, S. (1969). Biochimica et Biophysica Acta, 192, 542.

Lindahl-Kiessling, K., and Peterson, R. A. (1969). Experimental Cell Research, 55, 81 .

Mandel, T. E. (1972). Nature New Biology, 239, 112

Mayhew, E., and Weiss, L. (1968). Experimental Cell Research, 50, 441.

Mehrishi, J. N. (1969). European fournal of Cancer, 5, 427.

Mehrishi, J. N. (1970). Vox sanguinis, 18, 27.

Mehrishi, J. N. (1972 a). International Archives of Allergy and Applied

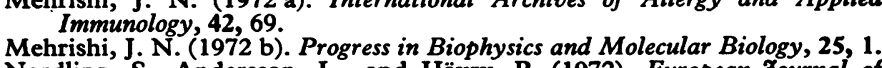

Mehrishi, J. N. (1972 b). Progress in Biophysics and Molecular Biology, 25, 1.
Nordling, S., Andersson, L., and Häyry, P. (1972). European fournal of Immunology, 2, 405.

Phillips, B., and Roitt, I. M. (1973). Nature New Biology, 241, 254.

Seiler, F. R., Johannsen, R., Sedlacek, H., and Zeiller, K. (1974). Transplantation Proceedings. In press.

Wilson, J. D., and Nossal, G. J. V. (1971). Lancet, 2, 788.

Zatz, M. M., Goldstein, A. L., Blumenfeld, O. O., and White, A., 1972., Nature New Biology, 240, 252.

Zeiller, K., Holzberg, E., Pascher, G., and Hannig, K. (1972). HoppeSeylers Zeitschrift für physiologische Chemie, 353, 105.

Zeiller, ot al. (1974). In press. 